\title{
COST AND RETURN ANALYSIS OF GINGER PRODUCTION IN THE GUINEA
} SAVANNAH OF NIGERIA

\author{
J.E. Ewuziem and V.O.Onyenobi \\ National Root Crops Research Institute Umudike Nigeria \\ E mail: juziem2000@yahoo.com
}

\begin{abstract}
The study focuses on the cost and return analysis of ginger production in the guinea savannah agro ecology of Nigeria. The study is aimed at highlighting the profitability of ginger production with a view to informing and influencing farmers and relevant stakeholders. The study was conducted at Kajuru, Kaduna state in the Guinea Savannah agro ecological zone of Nigeria, during the 2010 and 2011 planting seasons. The objectives of the study include: to estimate the cost and returns of ginger production, determine the returns cost ratio of cultivating one hectare of ginger in the study area. To achieve these, one hectare of farm land was planted out with the UGlvariety of ginger, during 2010 and 2011 planting seasons. All agronomic practices were applied as recommended. Data were collected using the cost route approach on all the inputs used. Data analyses was carried out using the income statement to determine the gross return, total cost of production, profit and the returns cost ratio. The result shows that the total cost of cultivating a hectare of ginger in the area is $\square 677572.5$, with a gross return of $\square 1,382,482$. Also a returns cost ratio of 2.04:1 was obtained. This implies that ginger farming in the guinea savannah of Nigeria will attract 2.04 times the capital investment of the farmer. Among the various inputs, cost of labour $(50.57 \%)$ and planting materials (30.38\%) contributed higher to the total variable cost of production. It was therefore concluded that ginger production is a viable enterprise in the study area. The study recommended that ginger farmers should employ labour saving devices in their operations while some of them consider going into commercial seed ginger production using technologies developed by research Institutes.
\end{abstract}

Key words: ginger, production, Nigeria, guinea, savannah

\section{http://dx.doi.org/10.4314/jafs.v10i2.3}

\section{INTRODUCTION}

Agriculture remains a major sector of the Nigerian economy, despite emphasis on crude oil. This is so because majority of Nigerians rely on agriculture for their livelihood. It is increasingly evident that improved agricultural development and growth can offer a pathway to poverty reduction. This is why the agricultural transformation agenda of the present government of Nigeria is placing emphasis on economic empowerment of Nigerian farmers. It is estimated that Nigeria has about 71.2 million hectares of available agricultural land and 
Journal of Agriculture and Food Sciences

Volume 10 Number 2, October 2012 pp. 26-36.

J.E. Ewuziem and V.O.Onyenobi

about half of which is currently being utilized (Ewuziem and Nwauzor 2011). Even the cultivable land is threatened by urbanization and other development activities.

Ginger is a monocotyledonous herbaceous perennial plant belonging to the family zingiberaceae. Its flavouring type is classified as Zingiber officinale which is the most popular hot spice in the world, belonging to the order; suitaminae and the family Zingiberaceae. Ginger is a unique crop because of its low volume and high value attributes. The crop is suitable for cultivation in marginal lands, implying that ginger cultivation can accommodate urbanization because it does not require large land space. Nigeria has over the years occupied a strategic position in the global production and export of high quality ginger.

Ginger is one of the world's most popular and useful plants, being used for centuries as spices for flavouring food and as a medicinal plant. About half of its world's production comes from India, whereas, its cultivation is extended to China, Australia, Malaysia, Nigeria, Fiji, Brazil and Mexico (Sanderson et al., 2002). It is an important spice used as a condiment in vegetable preparations. It is also an important ingredient in herbal medicines for the treatment of rheumatism, nervous diseases, gingivitis, toothache, asthma, stroke, constipation and diabetes (Awang, 1992; Wang \& Wang, 2005; Tapsell et al., 2006). The oil and oleoresins obtained from ginger are also used in many food items, soft drinks and beverages (Singh et al., 2008). Al-Achi (2007) reported that ginger is contraindicated in people suffering from gallstones, as the herb promotes the release of bile from the gall bladder. Also, Chen et al (2007) noted that ginger compounds are active against a form of diarrhea, which is the leading cause of infant death in developing countries. Ginger has been found effective for treating nausea caused by seasickness, morning sickness and chemotherapy (Ernst and Pittler 2000). Over the last decade, ginger has been found to be anti carcinogenic through many different pathways. It has been shown to prevent initiation, promotion, and progression of various types of cancer (Bisset and Wichtl 1994).

Large scale production of ginger in Nigeria started in 1927; (Arene et al 1986) in Southern Kaduna (Guinea Savanna Agro Ecology), especially within the Jemma federated districts in the present Kaduna State (Kwoi, Kubacha, Kafanchan and Kagarko areas) and in the neighbouring parts of Plateau State (Bako, 1984). This occurred during the search for a crop to generate internal trade (Erinle 1988). Efforts were intensified to increase and spread the cropping area and widen the genetic base. Considerable success was achieved in this area following the result of the ecological adaptation trials at the National Root Crops Research Institute Umudike. In recent times, ginger cultivation has been introduced into the rainforest agricultural zone of Nigeria.

Ginger is basically an export crop because of its high demand in advanced medical and confectionary industries. About $10 \%$ of the produce is consumed locally as fresh ginger while the remaining $90 \%$ is dried for both local consumption and export. According to Ezeagu (2006), 20\% of the dried ginger is consumed locally for various uses and $80 \%$ is exported.

Journal of the Faculty of Agriculture and Veterinary Medicine, Imo State University Owerri website: www ajol.info 
Journal of Agriculture and Food Sciences

Volume 10 Number 2, October 2012 pp. 26-36.

J.E. Ewuziem and V.O.Onyenobi

The two main varieties of ginger indigenous to Nigeria are UG1 (Yellow ginger Taffin Giwa) and UG2 (Black ginger Yatsun Biri) which were predominantly cultivated in the country until 1986 when other cultivars (Maran, Himachal Pradesh, Rio de Janeiro, Wynad Local and Saint Vincent) were introduced from India (Okwuowulu 1992). Research has shown that ginger grows well in the rainforest and the guinea savannah agro ecological zones of Nigeria. Ginger requires a favourable climate to grow; it does best in sandy clay-loam soils. These favourable conditions abound in the southern Kaduna districts, major producers of the crop and in the guinea savannah zones of northern Nigeria. Despite efforts made by the National Root Crops Research Institute Umudike, to diversify the production areas of ginger in Nigeria, cultivation of ginger is still predominant in the southern Kaduna districts of Jabba and Kagarko especially in Kwoi, Walijo, Kachia and Kubacha.

Cost and returns analysis is an important appraisals aimed at keeping track of the viability of enterprises and serve as a guide to future investments. It shows in monetary terms, the relationship between the various cost items and the total cost and net return. Authors like Asumugha et al (1992) have attempted to determine the cost and returns of producing ginger in Nigeria, however current information is needed in line with the societal demands. This information is most needed in the Guinea savannah, as there exists paucity of information on the cost of producing ginger and the returns associated with it in the area. This study therefore is set out to provide the needed information with the following specific objectives: To estimate the cost and returns of cultivating 1 hectare of ginger, determine the Returns Cost Ratio of the enterprise and identify the percentage contribution of various inputs to the total cost of production.

\section{METHODOLOGY}

The study was conducted at the National Root Crops Research Institute's ginger research farms at Kajuru in southern part of Kaduna State, in the guinea savannah agro ecological zone of Nigeria. One (1) hectare of ginger was cultivated in each cropping season for two years (2010/2011) using the UG1 variety. The agronomic operations were carried out according to the Institute's recommended technology package for ginger cultivation. The assessment of the operating net returns was computed using the income or operating statements as used by Amaechi (2007) and Ewuziem et al (2009). This was achieved by the following analytical model;

$\mathrm{GR}=\mathrm{TVP}-\mathrm{TVC}$

Where

GR $=$ Gross Returns

TVP $=$ Total Value of Production

TVC $=$ Total Variable Cost.

The profit (П) was derived by deducting the Total Fixed Cost (TFC) from the Gross Return. $\Pi=$ TVP - TVC - TFC.

Journal of the Faculty of Agriculture and Veterinary Medicine, Imo State University Owerri website: www ajol.info 
Journal of Agriculture and Food Sciences

Volume 10 Number 2, October 2012 pp. 26-36.

Where

$\Pi=$ Profit

$\mathrm{TFC}=$ Total Fixed Cost .

$\mathrm{RCR}=\mathrm{GR} / \mathrm{TC}$

Where

RCR $=$ Returns Cost Ratio

$\mathrm{TC}=\mathrm{TVC}+\mathrm{TFC}$

A $R C R \geq 1$ is economically viable.

The value of the fixed cost was obtained by depreciating all farm implements used in the operation, using the straight line method of depreciation with the formula;

$$
\mathrm{D}=(\mathrm{P}-\mathrm{S}) / \mathrm{N}
$$

Where

$\mathrm{D}=$ Annual depreciation

$\mathrm{P}=$ Purchase price

$\mathrm{S}=$ Salvage or scrap value

$\mathrm{N}=$ Economic life span of asset.

According to Ray (1986), the scrap value of some of the assets like spades, shovels, buckets, rain boots and others were assumed to be zero because most of them are used until completely worn out to have any junk value attachment. No attempt was made to charge proportion of depreciation cost on assets such as vehicles or other items not solely used for the farming enterprises. For instance, institute's own vehicles used to convey workers and materials to the farm are also used for other activities including other research works. Therefore their services to the farms under consideration were treated and valued under contingency cost as applicable.

\section{THE FARM INCOME STATEMENT}

This is also called profit and loss account or income statement. Lee et al (1980) defines it as a summary of receipts and gains during a specified period, usually one year, less expenses and losses during the same period with net income or net loss resulting. It actually involved measurement of the farm's output and input in monetary value terms. Sawyer (1981) defines profits as the difference between total revenue and total costs. Net profit is the most important and interesting figure in the profit and loss account as this must be enough to cover living expenses and loan repayments (Amaechi, 2007).

Journal of the Faculty of Agriculture and Veterinary Medicine, Imo State University Owerri website: www ajol.info 
Journal of Agriculture and Food Sciences

Volume 10 Number 2, October 2012 pp. 26-36.

J.E. Ewuziem and V.O.Onyenobi

\section{RESULTS AND DISCUSSION}

The values expressed in table 1 below are average values obtained in the two cropping seasons of 2010 and 2011. The result shows that during this period, an average of 16.5 tons of fresh ginger rhizomes /hectare, was harvested and valued at $\square 1,986,207.5$ based on the prevailing market price of $\square 120,376.21$ /ton in the Guinea Savannah agro ecological zone of Nigeria. A Gross Return of $\square 1,382,482.5$ was realized. This is positive and wide, showing that such enterprise is highly profitable and viable as reported by Ater et al (2012). The total cost of production was estimated at $\square 677572.5$ with a profit of $\square 1,308,635$. This result is in agreement with the postulation of Ezeh, (1992) that for a business to survive in the short run, there is need to set the price of its produce to cover the variable cost of production. A Returns Cost Ratio of 1:2.93 was obtained, implying that for every $\square 1$ invested in ginger cultivation, the investor will benefit $\square 2.93 \mathrm{k}$, ceteris paribus.

\section{ASSUMPTIONS}

1. Labour cost is $\square 400.00$ per man day. This is the current rate approved for casual labour at National Root Crops Research Institute Umudike and used in the farm operations.

2. Since mulch materials are harvested within the farm area, the labour cost of cutting the mulch is used as a proxy for cost of mulch.

Among the variable cost components in the production of ginger in the guinea savannah of Nigeria, cost of planting materials exerts most pressure on the variable cost of production, taking $31.47 \%$ of the cost. This is shown in figure 1 below. Also from the figure, the cost of harvesting ginger in Nigeria is high (13.52\% of TVC). On the overall, production activities requiring labour contributed almost $50 \%$ of the total cost of production. This supports earlier reports by Ezeh, (1998) and Ezedinma (2000) that labour activities have been found to be the greatest constraint to all food crops production. This is due to the use of traditional implements which are labour intensive and time consuming; giving credence to Ogbonna et al (2009) that in Nigeria, human effort and not machines are used in most farm operations. Again, it takes 250,000 rhizomes to plant a hectare of ginger field, at a planting distance of $20 \mathrm{~cm} \times 20 \mathrm{~cm}$, enormous labour is required to accomplish this task. This means that for any production cost reduction strategy to be effective as it affects ginger in the guinea savannah agro ecological zone of Nigeria, labour and planting materials must be given priority attention.

On the overall, apart from inputs such as: planting materials, fertilizer, herbicides and fungicides, other inputs are labour based activities which when put together constitute over half of the total variable cost $(50.57 \%)$. This is shown in figure 2. This implies that labour requirement is the most important factor to be considered in the production of ginger in the guinea savannah agro ecological zone of Nigeria, followed by planting materials. Journal of the Faculty of Agriculture and Veterinary Medicine, Imo State University Owerri website: www ajol.info 
Journal of Agriculture and Food Sciences

Volume 10 Number 2, October 2012 pp. 26-36.

J.E. Ewuziem and V.O.Onyenobi

\section{CONCLUSION AND RECOMMENDATIONS}

This study has shown that ginger production in the guinea savannah agro ecological zone of Nigeria is a viable venture. The result indicates that the cost of cultivating a hectare of ginger in the study area during the cropping seasons under review is N677572.5, with a return of $\mathrm{N} 1,382,482.5$ showing a return cost ratio of 2.04:1. However, among the various production inputs, the costs of labour $(50.57 \%)$ and planting materials $(30.38 \%)$ contributed more to total variable cost. This implies that labour and planting material are important variables to be considered in ginger production in the guinea savannah of Nigeria. It is therefore recommended that

Ginger farmers in the guinea savannah should employ labour saving devices such as mechanization in their farm operations

Some ginger farmers should consider going into commercial production of seed ginger using technologies developed by research Institutes.

Since ginger production is a viable venture, private/public partnership should be encouraged to harness the potentialities of ginger as an export crop. 
Journal of Agriculture and Food Sciences

Volume 10 Number 2, October 2012 pp. 26-36.

J.E. Ewuziem and V.O.Onyenobi

\section{REFERENCES}

Al-Achi, Antoine (2007) A current look at Ginger Uses

(http://www.uspharmeist.com/oldformat. asp?) Retrieved on 02-08-2007

Amaechi, E.C.C. (2007) Capitalization and Efficiency of Small Seale Oil palm produce Processing mills in Imo State Nigeria. PhD Dissertation Michael Okpara University of Agriculture Umudike Nigeria

Arene O. B.; Orkwor, G. C.; Okwuowulu, P. A. (1986) Ginger Research in Nigeria. Tropical Root Crops and the African Food Crises. Proceedings of the ISTRC-AB held at Owerri, Nigeria. August 17-23, 1986, Ontario, IDRC (1987) 1X +197, iii, 89-93.

Asumugha, G.N., Njoku, O. And Eke-Okoro, O.N. (1992) Economic evaluation of Ginger production technology in the Rainforest zone of Nigeria

Ater, P.I., A. Soom and E.A. Weye (2012). Profitability of Goat Enterprise in Ibi Local Government Area of Taraba State, Nigeria. Proc. Of $26^{\text {th }}$ Ann. Conf. of Farm Management Assoc. of Nigeria, held at Michael Okpara University of Agriculture Umudike. Pp 170-174

Awang, D.V.C. 1992. Ginger. Can. Pharm. J., 125: 309-311.

Bako, I. 1984. Request for Information on Edible Ginger Cultivation in Northern Nigeria. (Personal communication) In Ginger in Africa and the Pacific Ocean Island (Okwuowulu 2005) CRC press ltd.

Chen, J.; Li-jiau, H. (2007) Ginger and its bioactive component inhibit enterotoxigenic eschemichia coli Heat-labile enterotoxic-induced Diarrhea in Mice" Journal of Agricultural and food chemistry 55 (21); 8390-8397. Doc; 10.1021/jfo71460f.

Erinle, I. D. (1988) An Overview of Ginger Research in the Northern States of Nigeria. Proceedings of the first National Ginger Workshop, Oct. 17-21, 1988, Umudike, Nigeria Pp 8-15.

Ernst, E.; Pittler, M. H. (2000) Efficiency of ginger for nausea and vomiting; a systematic review of randomized chemical trials. British journal of anesthesia 84 (3):367-371. AMID 10793599

Ewuziem, J. E; Amaechi, E.C.C and Onyenobi V.O (2009) "Analysis of ginger export from Nigeria (1989-2004)" Proceedings of $43^{\text {rd }}$ Annual conference of Agricultural Society of Nigeria, Abuja 367-370.

Ewuziem, J.E. and E.C. Nwauzor (2011) 'Ginger Research in Nigeria: Achievements, challenges and Prospects for Food Security' In Root and Tuber Crops Research for Journal of the Faculty of Agriculture and Veterinary Medicine, Imo State University Owerri website: www ajol.info 
Food Security and Empoerment NRCRI Umudike Nigeria. Snaaps Press Ltd Enugu. Pp 373-385

Ezedinma, C. (2000). Farm Resource Allocation and Profitability of Arable Crop Enterprise in Humid Forest Inland Valley Ecosystem: A Case Study of Ozu Abam I Southeen Nigeria UNISWA Journal of Agriculture, vol. 9:48-56

Ezeh, N.O.A (1992). Economics of Yam Flour Production: Implications for Research and development. Tropical Agriculture (Trinidad).69(1):51-57

Ezeh, N.O.A (1998). Economics of production and postharvest technology In: Food yams: Advances in research. G.C. Okwor, R.A. Asiedu and I.J.Ekanayake eds. NRCRI Umudike/IITA, Ibadan, Nigeria.: 187-214

Ezeagu, W. 2006. Ginger export. A paper presented at a 3-day National Workshop on massive

ginger production and processing for local industries and export; held at Fati Muasu

Hall, National centre for women development, Abuja.

Lee, W; F.M.D. Boehje; A.G. Nelson and W.G. Murray (1980) Agricultural Finance. Iowa State University Press, Ames, Iowa. 25-80

Ogbonna, M.C., Korieocha, D.S. and Anyaegbunam, H.N. (2009) Labour Productivity and Implications in sweetpotato production in southeastern agro ecological zone, Nigeria. Proc. of the $43^{\text {rd }}$ Annual Conference of Agricultural Society of Nigeria, Abuja Pp 338-341

Okwuowulu, P. A.; Ene, L. S. O.; Odurukwe, S. O.; Ojinnaka, T. I. 1989. Effect of time of planting and age at harvest on the yield of stem tuber and shoots in ginger (zingiber officinale Roseoe) in the rain-forest zone of Southeastern Nigeria. Exp. Agric 26, pp 209-212.

Okwuowulu, P. A. 2005. Ginger in Africa and the Pacific Island” In Ginger: The Genus Zingiber CRC press Ltd. Boca Raton London New York Washington, D.C. Pp 552

Sanderson, L., A. Bartlett and P.J. Whitfield. 2002. In Vitro and In Vivo studies on the bioactivity of a ginger (Zingiber officinale) extract towards adult Schistosomes and their egg production. J. Helminthol., 76: 241-247.

Sawyer, M.C (1981); the Economics of industries and farms. Theories, Evidence and Policy. St Martins press New York. 178. 
Journal of Agriculture and Food Sciences

Volume 10 Number 2, October 2012 pp. 26-36.

J.E. Ewuziem and V.O.Onyenobi

Singh, R., R.R. Sharma, S. Kumar, R.K. Gupta and R.T. Patil. 2008. Vermicompost substitution Influences growth, physiological disorders, fruit yield and quality of strawberry. Biores. Technol., 99: 8507-8511.

Tapsell, L.C., I. Hemphill, L. Cobiac, C.S. Patch, D.R. Sullivan, M. Fenech, S. Roodenrys, J.B.

Keogh, P.M. Clifton, P.G. Williams, V.A. Fazio and K.E. Inge. 2006. Health benefits of herbs and spices: the past, the present, the future. Med. J. Aust., 185: S4-S24.

Wang, W.H. and Z.M. Wang. 2005. Studies of commonly used traditional medicine-ginger. Zhon. Zh. Yao Za Zhi., 30: 1569-1573.

Journal of the Faculty of Agriculture and Veterinary Medicine, Imo State University Owerri website: www ajol.info 
Table 1: Average annual Income Statement per hectare of Ginger Cultivation for 2010/2011 planting seasons in the Guinea Savannah of Nigeria

\begin{tabular}{lclll}
\hline ITEMS & VALUE & SUB. & BALANCE & $\%$ of \\
& $(\mathbb{N})$ & TOTAL (\#) & (N) & TC \\
\hline
\end{tabular}

\section{REVENUE (TVP)}

16.5tons of fresh Rhizome

@ 120,376.21/ton

Total

\section{VARIABLE COST}

Operating

1. Labour (Mandays)

a. Land Preparation(156.5) 62,775

8.08

b. Planting

(161.5)

64,600

8.31

c. Herbicide appl.

1,600

d. Fungicide

1,000

51,800

f. Weeding

33,300

g. Fertilizer appl.

8,500

h. Harvesting

(204.75)

2. Planting Materials

(5tons)@N38,000/ton of

$20 \mathrm{gm}$ sett

3. Fertilizer $(300 \mathrm{~kg}$ of NPK

15:15:15@N8542/50kg including transport

4. Herbicides (gramozone + primextra) 8litres each @N2,775/litre

5. Fungicide (2litres

@N6,600/litre)

Total variable cost (TVC)

Gross Return (GR)

Dep. Cost of Farm Implements

12,250
$1,986,207.5$
0.21

0.13

6.67

10.50

24.46

18.18

603,725

$1,382,482.5$

Total fixed cost (TFC)

12,250

Journal of the Faculty of Agriculture and Veterinary Medicine, Imo State University Owerri website: www ajol.info 
Journal of Agriculture and Food Sciences

Volume 10 Number 2, October 2012 pp. 26-36.

J.E. Ewuziem and V.O.Onyenobi

\begin{tabular}{lccc}
\hline Total (TVC +TFC) & 615,975 & & 10.0 \\
Contingency (10\% of Total) & $61,597.5$ & & \\
Total Cost (TC) & 677572.5 & $\mathbf{1 , 3 0 8 , 6 3 5}$ & \\
Profit & & & \\
RCR & $\mathbf{2 . 0 4 : 1}$ & & \\
\hline
\end{tabular}

Figures in parenthesis under labour are Man days (Total of 646 man days).

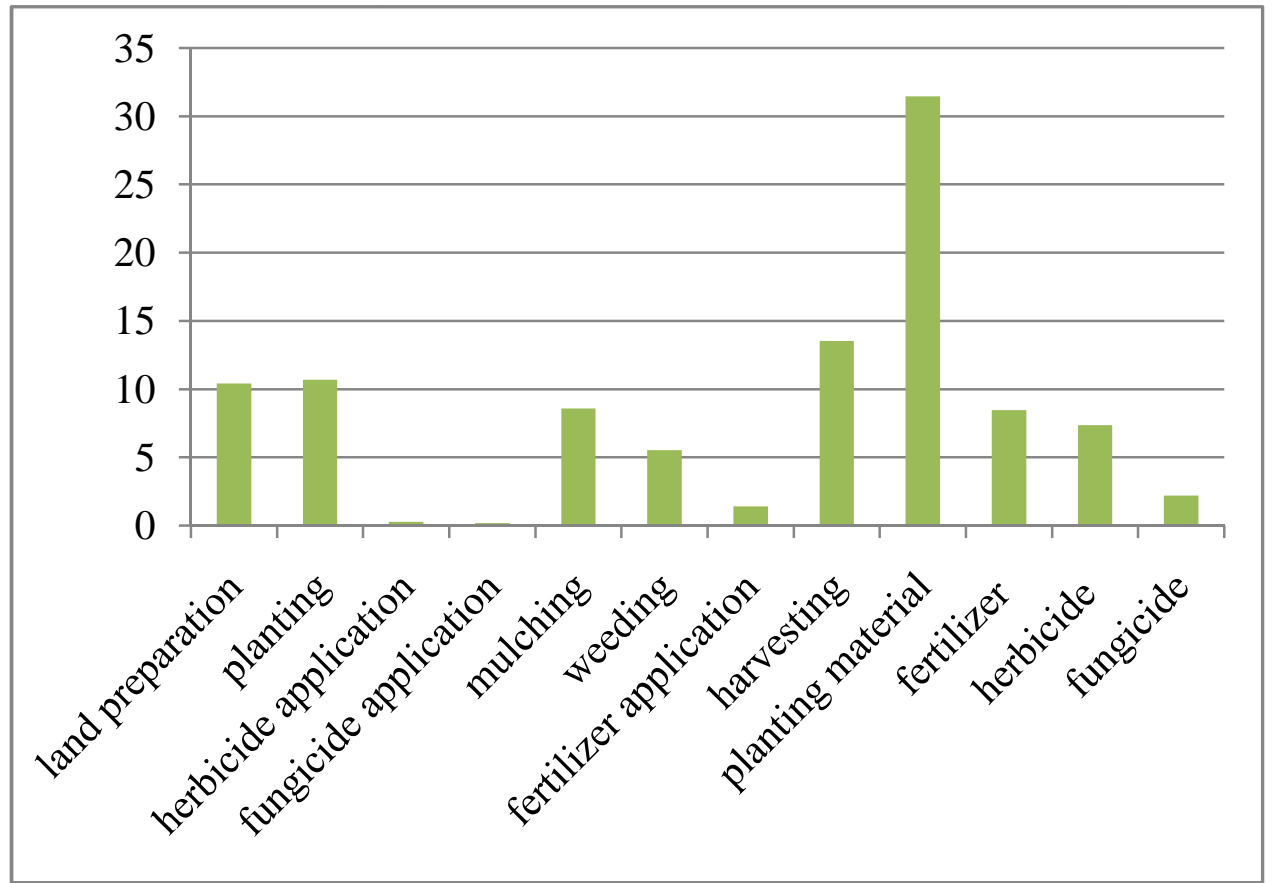

Figure 1: Percentage Contribution of operating cost items in ginger cultivation

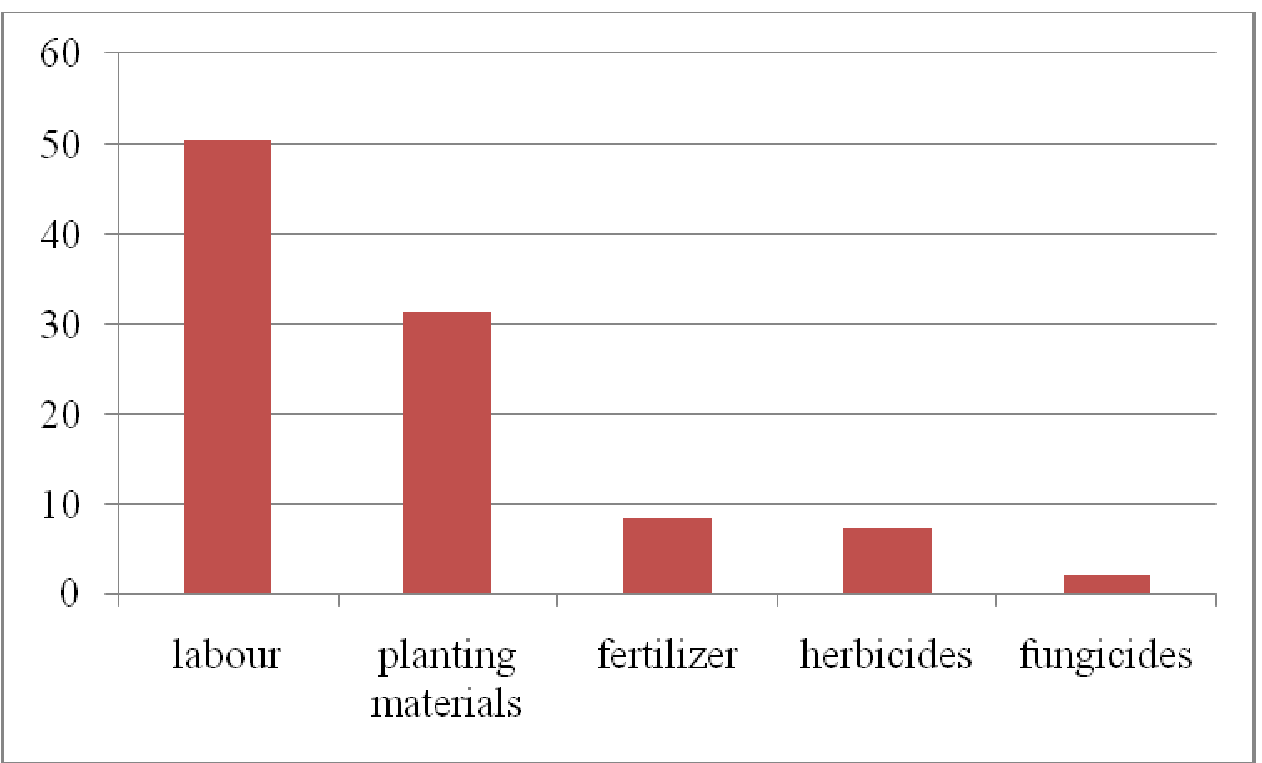

Figure 2: labour and other input requirements in ginger production

Journal of the Faculty of Agriculture and Veterinary Medicine, Imo State University Owerri website: www ajol.info 